Arsenije Vujović

dipl. pravnik, Beograd

\title{
PRILOG MISLI O MATERIJALNOJ PRAVOSNAŽNOSTI GRAĐANSKE PRESUDE*
}

\section{Uvodne napomene}

Kada se govori o pravosnažnosti presude, onda se misli na posledice pravosnažnosti, koje ona u formalnom i materijalno-pravnom smislu proizvodi. Sud, tokom cijelog postupka po službenoj dužnosti pazi, da li je stvar pravosnažno presuđena, i ako utvrdi da je parnica pokrenuta o zahtjevu, o kome je već pravosnažno odlučeno, odbaciće tužbu (čl. 333. st. 2. ZPP-a).

U pravnoj teoriji prisutna je podjela pravosnažnosti presude na formalnu i materijalnu pravosnažnost. Doduše, ova podjela nije jednodušno prihvaćena u pravnoj misli. Ima pravnih pisaca koji smatraju da je pravosnažnost presude nedjeljiva.

Svojstvo formalne pravosnažnosti se ogleda u nepobojnosti sudske presude. Presuda se ne može napadati u sledećim slučajevima: istekom roka za redovni pravni lijek, odricanjem od pravnog lijeka, odustankom, ako je lijek već izjavljen, donošenjem presude u poslednjem stepenu. Svojstvo formalne pravosnažnosti presuda stiče, prema svakoj stranci posebno.

Formalna pravosnažnost prethodi nastupanju materijalne pravosnažnosti - samo presuda, koja je postala pravosnažna prema svim strankama (u formalnom smislu) stiče dejstvo materijalne pravosnažnosti. Materijalna pravosnažnost dejstvujući svojom sadržinom kao ,snagom zakonske istine" potvrđuje egzistenciju (ili inegzistenciju) određenog subjektivnog prava, ili objavljuje konkretnu pravnu promjenu u pravnom poretku

* Rad primljen: 21. VII 2003, godine. 
države, otklanjajući neizvjesnost i nesigurnost u pravnim odnosima. Pravosnažna presuda je svrha pokretanja parničnog postupka.

\section{O materijalnoj pravosnažnosti presude u parničnom postupku}

Materijalna pravosnažnost presude odnosi se na sadržinu presude i na njeno dejstvo. Posmatrano sa pomenuta dva stanovišta, pravosnažna presuda dejstvuje neporecivošću svoje sadržine, u nekom drugom sporu (čl. 333. st. 2. ZPP-a). ${ }^{1}$ Pravosnažnošću presude (što je pravilo) zahvaćena je samo njena izreka, ${ }^{2}$ u čemu se ispoljava materijalna pravosnažnost sadržine presude. Dejstvo presude, u vidu njene neporecivosti se odnosi uvijek na drugi spor, sprečavajući vođenje parnice o istom zahtjevu (ne bis in idem).

Za postojanje presuđene stvari potrebno je da se ispune tri uslova: identitet stranaka u istoj ili obrnutoj ulozi, identitet zahtjeva i identitet činjeničnog osnova. Neophodno je da su ispunjena sva tri uslova (kumulativno) da bi sud mogao tužbu odbaciti, kao nedozvoljenu, zbog pravosnažno presuđene stvari (res judicata). Sud će tužbu odbaciti, vodeći računa po službenoj dužnosti da li je stvar pravosnažno presuđena, ili odlučujući o procesnom prigovoru tuženog. Ukoliko bi sud, ipak, meritorno odlučio o zahtjevu tužioca, počinio bi bitnu povredu iz čl. 354. st. 2. tač. 12. Zakona o parničnom postupku.

\section{Identitet stranaka}

Identitet stranaka postoji ako se radi o istim strankama. Ukoliko se umjesto stranke u docnijoj parnici pojave u stranačkoj ulozi njeni univerzalni sukcesori (npr. naslednici) ima se smatrati da je ispunjen uslov, koji se odnosi na identitet stranaka i sud će tužbu odbaciti, ukoliko su ispunjena i ostala dva uslova. Identitet stranaka postoji i u slučaju, kada se u potonjoj parnici stranke pojavljuju u izmijenjenim ulogama, u odnosu na raniju parnicu, koja je vođena između istih stranaka i koja je pravosnažno okončana. Tako je Viši trgovinski $\operatorname{sud}^{3}$ u jednoj svojoj odluci zauzeo sledeći stav: „Osnovan je prigovor presuđene stvari ako tužilac u sporu ostvaruje pravo koje se isključuje pravom tuženog o kome je već donijeta pravosnažna presuda, u sporu koji je vođen između istih stranaka u promijenjenoj ulozi." Ovaj primjer iz sudske prakse je poučan i kada se radi o utvrđivanju identiteta zahtjeva, o čemu će biti riječi.

1 Dr B. Poznić, Građansko procesno pravo, Beograd 1983, osmo izdanje, str. 283.

2 M. Janković, Ž. Janković, H. Karamarković i P. Petrović, Komentar ZPP-a, Beograd 1977, str. 399. Ovi autori zastupaju stav: „Obrazloženje presude doprinosi razumijevanju i utvrđivanju istovjetnosti zahtjeva, pa u tom smislu, i ono, na izvjestan način, učestvuje u pravosnažnosti".

${ }^{3}$ Presuda Višeg trgovinskog suda P̌̌. 757/02, od 21.11. 2002. godine. 
Identitet parničnih stranaka međutim, ne postoji, u slučaju kada je u potonjoj parnici zasnovano suparničarstvo solidarnih dužnika u ulozi tuženih, a u parnici koja je pravosnažno okončana samo je jedan od tuženih bio obavezan na plaćanje. Tako se u presudi Višeg trgovinskog suda ${ }^{4} \mathrm{u}$ Beogradu navodi: „Prigovor presuđene stvari se ne može uvažiti kada su prvo i drugo tuženi solidarni dužnici tužioca u jednoj parnici u kojoj je samo prvotuženi obavezan na plaćanje, jer tužilac bira koga će utužiti i od koga će naplatiti utuženi i dosuđeni iznos, a tuženi se nakon isplate međusobno obračunavaju za izvršenu isplatu."

\section{Identitet zahtjeva}

Identitet zahtjeva postoji, ako se u docnije zasnovanoj parnici traži pravna zaštita istog sadržaja, o kojoj je već, u ranijoj parnici pravosnažno odlučeno. Zahtjevi ne smiju da budu kontradiktorni, tj. da se međusobno isključuju. Tako je Savezni sud ${ }^{5}$ u jednoj svojoj odluci zauzeo stanovište: „Parnice su identične i radi se o presuđenoj stvari, ako je u obje parnice istaknut sadržajno isti zahtjev i ako su postavljeni zahtjevi kontradiktorni, kada osnovanost jednog zahtjeva isključuje mogućnost da bude osnovan drugi zahtjev". Za ocjenu, da li se radi o presuđenoj stvari, nije od značaja pravni osnov zahtjeva (za koji sud ionako nije vezan - čl. 186. st. 3 . ZPP-a). Tako Vrhovni sud Srbije ${ }^{6}$ u jednoj svojoj odluci konstatuje: „Predmet tužbenog zahtjeva se ne određuje sa stanovišta pravnog osnova navedenog u tužbi, jer sud po članu 186. stav 3. ZPP-a tim navodom nije vezan. Određuje se sa stanovišta činjenica koje obrazuju njegov stvarni i pravni identitet." Zahtjevi u pogledu visine potraživanja odnosno obima ovlašćenja, ne moraju biti isti u obje parnice, da bi se stekao uslov u pogledu identiteta zahtjeva. Vrhovni sud Hrvatske ${ }^{7}$ u jednoj svojoj odluci stao je na stanovište: „Osnovan je prigovor presuđene stvari, ako tužitelj traži da se utvrdi, da je on u $1 / 2$ dijela suvlasnik neke stvari, a u ranijem sporu, među istim strankama je tužitelj pravomoćno odbijen sa zahtjevom da se utvrdi da je on vlasnik te stvari." Dakle, vršenje svojinskih ovlašćenja u alikvotnom dijelu, sadržano je u vršenju svojinskih ovlašćenja, na cijelu stvar (shodno načelu da je manje sadržano u većem).

\section{Identitet činjeničnog osnova}

Identitet činjeničnog osnova postoji ako tužilac svoj pravozaštitni zahtjev u oba spora izvodi iz istih činjenica, odnosno iz istog životnog do-

\footnotetext{
4 Presuda Višeg trgovinskog suda Pž. 857/02, od 13. 01. 2003. godine.

5 Odluka Saveznog suda Gzs 36/74.

6 Rješenje Vrhovnog suda Srbije Rev. 3603/02. od 19. 09. 2002. godine.

7 Odluka Vrhovnog suda Hrvatske Gz. 1621/75. od 19. 02. 1976. godine.
} 
gađaja. Tako Vrhovni sud Jugoslavije ${ }^{8}$ u jednoj svojoj odluci rezonuje: „....što u konkretnom slučaju, iako stoje prva dva uslova (misli se na identitet stranaka i identitet zahtjeva - prim. autora) ne stoji treći uslov - identitet činjeničnog stanja, jer tužilac, kao dužnik, u ovom drugom sporu traži povraćaj dobrovoljno plaćenog iznosa, a osnov povjeriočevog držanja tog prvog iznosa otpao je zato što je povjerilac taj drugi iznos naplatio i drugi put, po izvršnom naslovu, prinudnim putem." Ukoliko sud nađe, da je prigovor presuđene stvari neosnovan, dužan je da odluku, kojom je prigovor odbijen, unese u odluku o glavnoj stvari. Viši trgovinski sud u Beogradu9, u jednoj svojoj odluci, navodi: „Prigovor pravosnažno presuđene stvari kao procesnopravni prigovor sprečava vođenje postupka protiv tuženog o istom zahtjevu shodno načelu ne bis in idem, i odluka suda o ovom prigovoru se unosi u odluku o glavnoj stvari dok je odluka o prigovoru zastarjelosti dio obrazloženja prvostepene odluke i ona se ne unosi u izreku". Međutim, ako je u parnici donijeto rješenje o odbacivanju tužbe (npr. zbog nedostatka određenih procesnih pretpostavki za postupanje suda) i ono postalo pravosnažno, nova parnica po ponovljenoj tužbi ne može biti okončana odbačajem tužbe zbog res judicata. U jednoj svojoj odluci Vrhovni sud ${ }^{10}$ Srbije stao je na stanovište: „Tužilac je podnio novu tužbu protiv istog rješenja o prestanku radnog odnosa. Ona je pravosnažno odbačena iz istog razloga. Dakle, zbog neblagovremenosti. Sudovi nijesu primijenili odredbe o odbacivanju tužbe zbog presuđenosti, samo zato što se odredbe o ovoj procesnoj smetnji ne primjenjuju, shodno, i na rješenja." Naime, ukoliko je sud odbacio tužbu, kao nedozvoljenu, jer je našao da postoje određene procesne smetnje za njegovo postupanje, na taj način nije meritorno odlučio o predmetu spora, niti je dao odgovor na pitanje o osnovanosti tužbenog zahtjeva (što bi podrazumijevalo unošenje u odluku činjenične i pravne ocjene spora).

\section{Materijalna pravosnažnost $\mathbf{i}$ intervencijsko dejstvo presude}

$\mathrm{Na}$ ovom mjestu biće riječi o pomjeranju granica pravosnažnosti sudske presude, sa učinkom na treća lica. Umješač (intervenijent) je treće lice, koje ima pravni interes da neka od parničnih stranaka uspije u sporu, kojoj se to lice pridružilo, kontrolišući način na koji stranka vodi spor, pomažući joj da uspije u parnici." Pravni interes je samo jedan od uslova, koji treće lice mora ispunjavati da bi steklo procesni položaj umješača u parnici. ${ }^{12}$

8 Odluka Vrhovnog suda Jugoslavije Gž. 46/79, Zbornik sudske prakse, 2-3, 180.

9 Rješenje Višeg trgovinskog suda Pž. 3733/02. od 13. 01. 2003. godine.

10 Presuda Vrhovnog suda Srbije Rev. II 1186/02. od 5. 09. 2002. godine.

11 Dr G. Stanković, Intervencijsko dejstvo presude, Pravni Život, br. 12/01, str. 5.

12 Umješač mora da ima poslovnu sposobnost, da parnica teče, da sud odlukom prihvati miješanje u parnicu. 
Nakon neuspjeha stranke u ranijem sporu, kojoj se bio pridružio, umješač, sada u ulozi stranke u parnici koja teče (najčešće ima položaj tuženog) ne može dovesti u sumnju tačnost zaključka suda o postojanju određenih činjenica, niti može sa uspjehom osporiti pravnu ocjenu spora. Intervencijsko dejstvo presude, dakle, proizvodi sveobuhvatan učinak na odnose stranaka u docnijoj parnici.

Intervencijskim dejstvom presude nije samo zahvaćena njena izreka, što je slučaj kod pravosnažnosti, već i utvrđenje činjenica i pravno shvatanje suda, što se dovodi u vezu sa procesnom ulogom umješača u parnici, u kojoj on, iako nema položaj stranke, može preduzimati određene procesne radnje (ne može preduzimati one radnje, koje je mogao preduzeti prije nego što je stupio u parnicu) i na taj način uticati na ishod spora. Dakle, intervencijsko dejstvo presude je u sadržajnom smislu šire od materijalne pravosnažnosti, kojom je zahvaćena, kao što je navedeno, samo izreka presude.

\section{Umjesto zaključka}

Pravosnažnost sudske presude ima veliki značaj za pravni poredak jedne države. Ona unosi sigurnost i izvjesnost u pravne odnose, sprečavajući da se vode parnice i u slučajevima kada su one već pravosnažno okončane. Inače, ne bi bilo kraja besmislenom parničenju stranaka, što bi dovelo do potpune nesigurnosti kada je u pitanju vršenje subjektivnih prava, a pravni položaj njihovih titulara bi bio neizvjestan. 